\title{
Post modern cross comparative analysis on the mosque ornamentation in Malaysia: (a case study of Charles Jencks)
}

\begin{abstract}
Ornamentation is one of the elements in mosque which is almost considered as a compulsory element by the common people. Most of these ornaments are using the precedent from Middle East, such as geometry, floral and arabesque (Utaberta, 2014). Many architects are using revivalism approach of past architectural building such as the Putra Mosque, glorious son of Malaysia. The Putra mosque adopts distinct Islamic architecture that calls on a foreign eclectic revivalism (historicism design approach) of the Persian (Iranian) vocabulary found during the glorification of Safavid period (Utaberta 2012). Ornamentation in Islamic building has recorded in many books. describe that one of the first ornamentation in Islamic Building found in Persia which is using revivalism approach in designing ornament in its column. Ornamentation is the key element that is used in most mosques all over the world. The aim of this writing is to provide the Charles Jencks's approaches to evaluating ornamentation system in mosque especially in Malaysia.
\end{abstract}

Keyword: Mosque in Malaysia; Ornamentation; Post-modernism 